\title{
TRÊS CONTOS DE LIMA BARRETO E DE MONTEIRO LOBATO: ESMIUÇANDO O BRASIL-REPÚBLICA
} Tâmara Abreu*

(iD) https://orcid.org/0000-0002-5824-9955

Como citar este artigo: ABREU, T. Três contos de Lima Barreto e de Monteiro Lobato: esmiuçando o Brasil-República. Todas as Letras - Revista de Língua e Literatura, São Paulo, v. 23, n. 2, p. 1-16, maio/ago. 2021. DOI 10.5935/1980-6914/eLETLT2 114654

Submissão: julho de 2021. Aceite: julho de 2021.

Resumo: Os contos de Lima Barreto postos em confronto com os contos de Monteiro Lobato apresentam diversos pontos de semelhança na perspectiva adotada por cada um ao pensar o Brasil. Contudo, refletir sobre o Brasil por mero exercício filosófico ou discursivo não era do feitio desses escritores: a pena está a serviço de causas maiores, de dores coletivas e das lutas nacionais. Neste estudo comparamos os contos "O moleque" (BARRETO, 2010 [1918]), “O fisco" (LOBATO, 1946b) e "Negrinha" (LOBATO, 1946a).

Palavras-chave: Lima Barreto. Monteiro Lobato. "O moleque". "O fisco". "Negrinha".

\section{Descortinando OS SERTões}

Domecemos por um lugar comum: algumas obras literárias são genuinamente representativas do pensamento e da configuração social de uma época. Em se tratando dos primeiros anos do século XX no Brasil, 
Os sertões (1902), de Euclides da Cunha, Triste fim de Policarpo Quaresma $(1911)^{1}$, de Lima Barreto e Urupês (1918), de Monteiro Lobato, parecem formar, sob certas perspectivas, uma trilogia literária ${ }^{2}$. Cada um a seu modo e com os recursos narrativos de que dispunham (ensaio, romance, conto), esses intelectuais tiveram o condão de abalar a opinião pública e reconfigurar o horizonte de compreensão que o Brasil, pelo menos na sua porção instruída, tinha de si mesmo.

Os textos mencionados inscrevem-se no período da República Velha (18891930), marcado por crises sucessivas na economia e na politica. Golpes, trocas ministeriais, inflação, pobreza, concentração de renda, analfabetismo, autoritarismo, revoltas de civis e de militares, greves de trabalhadores, o caos dava o tom do novo regime. Comparecem na literatura desses autores as profundas contradições, o pessimismo e a denúncia de problemas sociais ligados às injustiças do pós-Abolição e a uma República que começara malfadada, fracassada em sustentar suas promessas de progresso e civilização.

O que dizem as pesquisas sobre a literatura brasileira do período republicano? Para estudiosos do assunto, uma grande referência ainda é o estudo no qual o historiador Nicolau Sevcenko (2003) elegeu Euclides da Cunha e Lima Barreto como objetos de cotejo em sua análise. Anteriormente, manuais de história da literatura já traziam, mas sem o aprofundamento de Sevcenko, alguns paralelos formulados por Lúcia Miguel Pereira (1950), entre Machado e Lima, e por Alfredo Bosi (1994), entre Lima e Graça Aranha. De modo geral, as gerações que nos antecederam não apostavam na construção de um diálogo entre a literatura de Lima Barreto e a de Monteiro Lobato. E quanto a hoje?

\section{LOBATO E LIMA: UM ENCONTRO POR ACONTECER}

As controvérsias sobre a ocorrência de um encontro pessoal entre Lima Barreto e Monteiro Lobato foram esclarecidas por Francisco de Assis Barbosa: o biógrafo transcreve o relato feito pelo próprio Lima em carta enviada ao amigo e editor Schettino. Na missiva, ele conta ter visitado Lobato no escritório da editora quando passava por São Paulo, a caminho de Mirassol ${ }^{3}$. Quanto ao encontro de seus escritos por meio de pesquisas acadêmicas, a distância entre esses autores parece ser mantida sem grandes alterações.

Além das questões de raça, gênero, classe, politica e loucura sobre as quais se debruçaram os estudiosos de Lima Barreto nos últimos anos, outros trabalhos abordam a relação entre o indivíduo e a cidade, as formas de representação do espaço urbano em que se movia o escritor, incluindo a geografia humana do eixo centro-subúrbio da capital carioca. Por sua vez, as pesquisas sobre Lobato versam, geralmente, sobre a sua literatura infantil, os seus contos para adultos, a vasta correspondência, as traduções/adaptações, a sua atuação como editor e

\footnotetext{
O romance Triste fim de Policarpo Quaresma foi publicado primeiro em folhetim, no Jornal do Commercio, Rio de Janeiro, em 1911. Saiu em livro apenas em 1915.

2 Faria sentido incluir Esaú e Jacó (1908), de Machado de Assis, nesse conjunto. Porém, o nosso foco não está no momento político específico de transição Império-República, do qual fala Machado. Interessa-nos, particularmente, investigar as obras literárias que abrigam representações do período imediatamente posterior: a fração da história que herdou as consequências da mudança de regime e de uma Abolição sem compromisso com a inclusão social - uma sociedade excêntrica na qual negros eram livres, mas não cidadãos.

3 Segundo o biógrafo, a carta de Lima a Francisco Schettino tem data de 21 de abril de 1921 e foi publicada na sua correspondência (BARBOSA, 1959, p. 329).
} 
empresário da cultura, a questão do petróleo, sua relação com os Estados Unidos e, recentemente, sobre raça e eugenia.

Os olhares sobre as relações entre Lima Barreto e seus contemporâneos costumam privilegiar os desafetos que punham em marcha suas diatribes: o mandarinato literário de Coelho Neto, o movimento feminista, a burguesia, os arrivistas de Botafogo, a corrupção, os bajuladores, os medalhões do editor Garnier, a mediocridade dos jornalistas, e os maus literatos - que ele personificava nas figuras de alguns acadêmicos consagrados, tais como Coelho Neto, Afrânio Peixoto e João do Rio.

Se a literatura de Lima e Lobato não tem sido objeto de atenção de comparatistas, a correspondência mantida entre eles de 1918 a 1922 tem despertado maior atenção em pesquisas recentes. Provavelmente, tal interesse se deu em função da publicação dessas cartas em nova edição, com notas, manuscritos e acréscimos ${ }^{4}$. No texto de apresentação ao leitor, Valéria Lamego (apud CAVALHEIRO, 2017, p. 10-11) dá a sua impressão:

Em minha primeira leitura destas cartas, sobressaíram o drama de Lima Barreto e a compreensão aflita de Monteiro Lobato da eminente decadência do escritor carioca. Lobato, por outro lado, vivia o começo de sua ascensão entre 1918 e 1919. [...]

Mas foi a admiração de Lobato pelo editado Lima, e vice-versa que perpetuou o convívio epistolar por tanto tempo.

O livro de Lima foi um fracasso. E um indignado Lobato culpa a capa e o título não muito comercial de seu autor. Mas, passada a primeira fase de atração e interesses mútuos, a correspondência revela uma amizade de muitas ideias comuns, de um intelectualismo bem-humorado, de muito chiste e crítica social entre dois escritores cujos hábitos e vida particular eram praticamente opostos.

As cartas apontam, sobretudo quando são lidas juntamente com outros textos escritos por eles na mesma época, a existência de muitas ideias em comum entre Lima Barreto e seu confrade paulista. As interpretações atuais a respeito da postura desses autores diante da questão racial, somadas ao desconhecimento da obra de cada um em seu conjunto - considerando o desafio de dar conta de tão vasta produção - são fatores que podem responder por uma visão de suposta distância ou aparente incompatibilidade entre seus escritos.

$\mathrm{Na}$ apresentação da edição dos contos completos de Monteiro Lobato, a crítica e pesquisadora Beatriz Resende (2014) aponta a contundência das imagens com as quais Lobato opera, na sua ficção, a fim de apresentar ao leitor a gente brasileira e sua trágica sorte. Para Resende (2014, p. 10), "o que torna as narrativas de Lobato originais, atribuindo-lhes um caráter revelatório comparável ao que Euclides da Cunha dá ao sertão e Lima Barreto aos subúrbios do rio de Janeiro, é apresentar ao leitor a imensa pobreza do país [...]". Esta é a chave de leitura que nos permitirá jogar luz sobre as relações possiveis entre os contos de Lima Barreto e de Monteiro Lobato. Mas voltemos um pouco à discussão para concluir o nosso levantamento de estudos sobre o tema.

4 Após constituírem assunto de um capítulo do estudo de Prado (2004), as cartas entre Lima e Lobato reaparecem organizadas por Lamego (2017) e são analisadas por Tin (2017) em contraponto a Prado (2004). 
Até o que nos foi possível verificar, exceto por dois artigos científicos ${ }^{5}$, as obras continuam a ser estudadas isoladamente em trabalhos acadêmicos. Aqui abrimos um parêntesis para registrar a brilhante interpretação de Paulo Moreira quanto ao tratamento dado à questão da mobilidade social e às relações raciais / sociais no Brasil em três contos: "O enfermeiro", de Machado de Assis (1896), "O engraçado arrependido", de Monteiro Lobato (1918), e "O homem que sabia javanês”, de Lima Barreto (1920). Para ele,

[...] Machado de Assis, Monteiro Lobato e Lima Barreto inauguram o modernismo em seu sentido mais amplo antes do evento da vanguarda modernista dos anos 1920, tocando numa ferida fundamental do tecido social brasileiro, ferida que a Abolição e a República deveriam ter tratado, mas que apenas transformaram no que os falantes de lingua inglesa chamam de "o elefante na sala" (the elephant in the room), uma presença sufocante que todos insistem em fingir ignorar (MOREIRA, 2014, p. 116).

Nesse sentido, a partir da nossa leitura dos contos completos de Lima Barreto postos em confronto com os contos completos de Monteiro Lobato, foi possivel encontrar diversos pontos de semelhança na perspectiva adotada por cada um ao pensar o Brasil. Contudo, refletir sobre o Brasil por mero exercício filosófico ou discursivo não era do feitio desses escritores: a pena está a serviço de causas maiores, de dores coletivas e das lutas nacionais. Estando hoje o Brasil mergulhado em novas - ou nem tanto - crises econômicas e politicas que comprometem o equilíbrio social e a democracia, pensamos ser oportuno trazer nossa pequena contribuição aos estudos comparativos dedicados a esses autores.

\section{O ENCONTRO DE DOIS LEITORES}

Em 1916, Lobato "descobriu” Lima Barreto nas páginas da revista portuguesa A Águia. A leitura de dois contos do autor, somada à recepção elogiosa de Triste fim de Policarpo Quaresma pela crítica nos jornais, despertou em Lobato a convicção quanto ao talento de Lima. Em carta de outubro de 1916 a Rangel, sentencia:

A ajuizar pelo que li, esse sujeito é romancista de deitar sombra em todos os seus colegas, os coevos e os coelhos, inclusive o Neto. Facílimo na língua, engenhoso, fino [...]. Bacoreja-me que temos pela proa o romancista brasileiro que faltava (LOBATO, 1964, p. 108).

Dois anos depois dessa carta de leitor admirado, já tendo publicado seu primeiro livro e se tornado um empresário da cultura, é o editor Lobato quem escreve diretamente ao romancista a famosa carta-convite:

\section{Prezadíssimo Lima Barreto:}

A Revista do Brasil deseja ardentemente vê-lo [sic] entre seus colaboradores. Ninho de medalhões e perobas, ela clama por gente interessante, que dê coisas que caiam no gosto do público. E Lima Barreto, mais do que nenhum outro, pos-

\footnotetext{
A pesquisa no acervo da Biblioteca Digital Brasileira de Teses e Dissertações (BDTD) e no Google nos mostrou que não há dissertações ou teses publicadas até o momento atual. No que concerne a artigos, encontramos apenas dois trabalhos: Silva e Bergamo (2012) e Moreira (2014).
} 
sui o segredo de bem ver e melhor dizer, sem nenhuma dessas preocupaçõezinhas de toilette gramatical que inutiliza metade dos nossos autores. Queremos contos, romances, o diabo, mas à moda do Policarpo Guaresma (CAVALHEIRO, 2017, p. 40).

E assim foi feito. Lima responde já anexando à sua carta os originais de Vida e Morte de M. J. Gonzaga de Sá e entra para o rol dos autores editados pela casa, publicando posteriormente também seus contos na Revista do Brasil. Logo no primeiro contato, Lobato usa a senha adequada para sinalizar ao romancista que eles tinham pontos em comum: a antipatia pelo rigor gramatical; o horror aos medalhões, cuja notoriedade não provinha do talento; o combate ao estilo enfadonho dos escritores "perobas".

Àquela altura, eram conhecidos os ataques de Lobato tanto ao caboclismo na literatura quanto aos novos padrões de expressão, surgidos com as vanguardas artísticas europeias, nas artes plásticas brasileiras. Da mesma forma, o escritor combatia os ranços de galicismo e lusitanismo na prosa brasileira - defeito que ele próprio assumia ter. Na sua correspondência, vê-se o esforço consciente de Lobato para expurgar tais excessos da própria pena durante os anos de formação literária. Lima tampouco apreciava a mania do caboclo, os excessos de adjetivação e a afetação encontrada por ele nos literatos da Academia Brasileira de Letras (ABL).

Assim como Lobato se opunha ao grupo de intelectuais e artistas que frequentavam os salões promovidos pelo Senador Freitas Valle na Villa Kyrial ${ }^{6}$, Lima não participava das altas rodas dos salões literários e contra eles lançava impiedosas críticas em suas crônicas na imprensa carioca. De um lado, fustigava os medalhões publicados pelo editor Garnier; de outro, mirava os intelectuais burgueses da zona sul e frequentadores da Rua do Ouvidor. Quanto ao futurismo de Marinetti e ao movimento modernista, tanto Lobato quanto Lima foram críticos dos novos códigos estéticos que ditavam moda nas revistas de literatura e de cultura do eixo Rio-São Paulo. Os textos que, cada um em seu meio, produziram ao longo do tempo, sinalizam que eles possuíam visões muito próximas sobre a literatura. Tal semelhança é também aferivel na correspondência de ambos e nas duas resenhas que Lima publicou sobre a obra de Lobato.

Na resenha intitulada Problema vital (1919), Lima Barreto louva a denúncia, mas faz uma justa crítica ao modo como Lobato problematiza a questão do saneamento, por mirar nas consequências e não na causa do problema. Lima elogia o trabalho dos médicos Artur Neiva, Carlos Chagas, Belisário Pena e outros, por identificarem corretamente as endemias que vitimavam a população brasileira, mas ele se opõe ao remédio oferecido. Lima chama Lobato à razão e, com propriedade, aponta-lhe o equivoco: a solução não é sanear simplesmente; não está no combate à cabana de sapê, mas no combate ao que lhe dá origem: o latifúndio. A solução está na luta contra o regime capitalista na agricultura.

Ainda na mesma resenha que comentávamos no parágrafo anterior, Lima exalta o talento de Lobato e o valor dos contos reunidos em Urupês (1918); considera espantoso que um escritor como Lobato tenha saído de uma escola literária tão formalista e afetada, de uma cidade tão europeizada. Segundo a opinião do escritor carioca,

6 Para maiores detalhes sobre a Villa Kyrial, ver Camargos (2000). 
O sucesso de Monteiro Lobato, lá, retumbante e justo, fez-me mudar de opinião. A sua roça, as suas paisagens não são cousas de moça prendada, de menina de boa família, de pintura de discípulo ou discípula da Academia Julien; é da grande arte dos nervosos, dos criadores, daqueles cujas emoções e pensamentos saltam logo do cérebro para o papel ou para a tela. Ele começa com o pincel, pensando em todas as regras do desenho e da pintura, mas bem depressa deixa uma e outra cousa, pega a espátula, os dedos e tudo o que ele viu e sentiu sai de um só jato, repentinamente, rapidamente.

O seu livro é uma maravilha nesse sentido, mas o é também em outro, quando nos mostra o pensador dos nossos problemas sociais, quando nos revela, ao pintar a desgraça das nossas gentes roceiras, a sua grande simpatia por elas. Ele não as embeleza, ele não as falsifica; fá-las tal e qual (BARRETO, 2017, p. 146-147).

Há quem veja com desconfiança a amizade registrada na correspondência mantida entre Lima Barreto e Monteiro Lobato. Em resenha na revista Quatro Cinco Um, a historiadora e antropóloga Lilia Schwarcz, pesquisadora da obra de Lima e biógrafa do escritor, tece suposições quanto a uma suposta desavença com Lobato que Lima teria preferido evitar em vez de declarar (SCHWARCZ, 2017). Discordamos do que nos parece mera especulação. A pesquisadora também defende a hipótese de que Lima teria silenciado e se esquivado da polêmica em torno de Urupês, atribuindo ao escritor carioca uma postura que não era de seu feitio, pois calar ideias, pisar em ovos, ou usar de meias-verdades eram diplomacias incompativeis com o temperamento de Lima Barreto.

Em nova resenha intitulada A obra do criador de Jeca-Tatu (1921), Lima faz sua segunda e última crítica literária sobre Lobato. A citação é extensa, mas constitui valioso testemunho de Lima Barreto em sua impressão de leitor de Monteiro Lobato. Leitor experiente e reservado, de espírito franco, Lima manifesta seu apreço pela obra de Lobato:

[...] o Sr. Lobato viveu ou nasceu na região a que chamam "norte paulista", o vale da parte de São Paulo do Paraíba do Sul. É ela que ele descreve com tanta ternura e emoção contida nos seus livros de ficção. Ele viu a sua decadência; ele relembra seu esplendor passado. Certamente, quando menino, brincou lá com aqueles Jecas; e é a sua saudade, é a sua simpatia, é a sua mágoa por não vê-los prósperos, que fez pintá-los como pintou. Isto está a ver-se nas suas Cidades Mortas, livro seu, talvez mais curioso que o famoso Urupês, que tanto escandalizou o patriotismo indígena.

No seu último livro - Negrinha - há um conto - "O jardineiro Timóteo" - que denuncia bem esse seu feitio de sentir. Deve-se lê-lo para bem perceber o pensamento geral que domina a produção do autor da Bucólica.

[...]

Toda a sua obra é simples e boa, animada pela poesia da sua terra, seja ela pobre ou farta, seja agreste ou risonha: mas é cheia de sadia verdade a sua literatura.

A sua visualidade artística e literária, apesar da limitação do campo, abrange um arco de horizonte muito mais amplo do que o do comum dos nossos escritores. O que se evola de suas palavras não é ódio, não é rancor, não é desprezo, apesar da ironia e da troça; é amor, é piedade, é tristeza de não ver o Jeca em condições melhores. 
Basta ler este conto - Negrinha - com que intitula o seu último livro, para nos impregnarmos da sua alma compassiva, descobrir a sua entranhada afeição pelos que sofrem e pensam neste mundo.

Não há no Sr. Monteiro Lobato nenhuma das exterioridades habituais dos escritores: pompa de forma, transbordamentos de vocabulário e de imagens; há um grande sonho intimo de obter a harmonia entre todos os homens e destes com a Terra, nossa mãe comum.

$E$, se a Arte, como quer Hegel, é a ideia que se procura, que se acha e que se vai além dela, Monteiro Lobato é um grande e nobre artista (BARRETO, 2017, p. 244-246).

Ao ler o artigo na Gazeta de Notícias, Lobato escreve a Lima afirmando ter se sensibilizado muito com o texto lido e que, dentre os muitos críticos que analisavam a sua obra, nenhum o compreendera de forma tão límpida como Lima Barreto.

\section{Negrinha, HistóRIAS E sonhos}

Lima Barreto e Monteiro Lobato, tanto pelos contos e crônicas que assinavam na imprensa periódica quanto pelos livros publicados, eram dois nomes incontornáveis da prosa brasileira nos arredores dos anos 1920. Não por acaso, veio de Antonio Candido o insight no qual ele afirma que Lobato seria "um pendant do carioca Lima Barreto" (CANDIDO, 1944). Vejamos: um pendant só existe, por definição, dentro de um par. De acordo com o Houaiss um pendant pode ser definido como "Cada um de dois objetos de arte que, destinados a serem dispostos simetricamente, formam um par" (HOUAISS, [s. d.]).

A metáfora formulada por Antonio Candido (1944) para qualificar a escrita de Monteiro Lobato coloca-o em correspondência direta com a pena de Lima Barreto. Mas em que consistiriam as simetrias entre essas duas literaturas? Como traçar, a partir de trajetórias sociais e realidades supostamente tão díspares, uma linha paralela? Depende da perspectiva adotada pelo leitor.

Tentando evitar a expansão excessiva do corpus de textos analisados, o recorte inicial adotado para este estudo se concentrou nos contos publicados em torno de 1920. Inicialmente publicados em periódicos e depois reunidos em livro, os textos presentes nos títulos Histórias e sonhos (1920), de Lima Barreto, em Urupês (1918), Cidades mortas (1919) e Negrinha (1920), de Monteiro Lobato, revelaram-se para nós uma teia de relações de múltiplas facetas. Dentre as dezenas de contos reunidos nesses volumes, selecionamos três: "O moleque", "O fisco" e "Negrinha". O primeiro é o conto de abertura de Histórias e Sonhos, e os demais aparecem em diferentes edições de Negrinha. Do ponto de vista de sua materialidade, segue um exercício preliminar de comparação entre as edições de 1920.

Histórias e sonhos foi o primeiro e último livro de contos de Lima Barreto: a única seleta de seus contos organizada e publicada por iniciativa própria junto ao editor e amigo Francisco Schettino. Esse foi seu último livro publicado em vida, reunindo 19 textos já publicados anteriormente em periódicos, perfazendo um total de 180 páginas. O pequeno volume foi impresso em papel jornal, fonte pequena e diagramação de baixa qualidade, apesar das páginas ornadas com 
cabeçalho decorado. Os paratextos são muitos: dedicatória, prefácio, índice, errata, observação/posfácio e juízos críticos.

Negrinha, por sua vez, teve várias edições e apresenta feição diversa em termos gráficos. Em sua primeira edição, Negrinha tinha apenas seis contos dispostos em 125 páginas, estética sóbria, fonte confortável, boa diagramação e foi impresso em bom papel. Segundo pesquisa de Milena Martins (2003), os livros anteriores, Urupês e Cidades mortas, tinham maior número de contos e um prefácio explicando ao leitor que aqueles textos já circulavam na imprensa antes de serem reunidos em volume impresso. Em Negrinha, não há nenhum prefácio ou posfácio. Outra diferença é o preço: Negrinha custava bem mais barato, alinhando-se aos novos projetos comerciais do editor ${ }^{7}$. Saindo da materialidade das obras, vamos aos textos.

\section{Molegues E NEGRINHAS: FILHOS DE UMA PÁTRIA-MÃE NADA GENTIL}

Os contos selecionados para a nossa leitura comparada foram "O moleque", de Lima Barreto e "O fisco" e "Negrinha", de Monteiro Lobato. Tendo sido publicados entre 1918 e 1920, esses três contos têm como protagonistas crianças que se identificam pela condição social, tanto no subúrbio carioca de Inhaúma quanto no bairro operário do Brás: a miséria. Negrinha tem sete anos, mas não tem nome; Pedrinho tem nove anos; e Zeca tem nove ou dez anos, segundo o narrador.

Publicado originalmente em 1918, na revista $A B C$, "O moleque" conta a história de José, o Zeca, filho único da viúva Dona Felismina. A começar pelo nome, Felismina era uma mulher de virtude.

Dona Felismina gozava de toda a consideração nas cercanias e até de crédito, tanto no Antunes, como no Camargo da padaria. Além de lavar para fora, tinha uma pequena pensão que lhe deixara o marido, guarda-freios da Central, morto em um desastre. Era uma preta de meia-idade, mas já sem atrativo algum. Tudo nela era dependurado e todas as suas carnes, flácidas. Lavava todo o dia e todo o dia vivia preocupada com o seu humilde mister. Ninguém lhe sabia uma falta, um desgarro qualquer, e todos a respeitavam pela sua honra e virtude. Era das pessoas mais estimadas da ruela e todos depositavam na humilde crioula a maior confiança (BARRETO, 2010, p. 145-146).

Felismina traz no corpo as marcas da degradação presentes também ao seu redor, no subúrbio mal-arruado e maltratado que abrigava a gente humilde de Inhaúma, um dos "poucos lugares da cidade que conserva ainda o seu primitivo nome caboclo, zombando dos esforços dos nossos edis para apagá-lo" (BARRETO, 2010, p. 143). A crítica ao apagamento da memória do Brasil promovido pelas autoridades públicas ao substituir nomes de lugares em tupi por nomes banais é, por sinal, o mote de abertura do conto de Lima Barreto.

Desde o bota-abaixo ${ }^{8}$, processo radical de reformas urbanas empreendidas no Rio de Janeiro a partir de 1903, durante a gestão municipal de Pereira Passos, o escritor já abordava em suas crônicas os problemas decorrentes das demoli-

7 Sobre as diferenças no modo de organização dos textos enfeixados nas edições dessa obra ao longo dos anos, consultar Martins (2003).

8 "Bota-abaixo" constitui um dos verbetes do Dicionário da Política Fluminense e está reproduzido no Atlas Histórico do Brasil, do Centro de Pesquisa e Documentação de História Contemporânea do Brasil (CPDOC) da Fundação Getulio Vargas (FGV). Disponível em: https://atlas.fgv.br/verbetes/o-bota-abaixo. Acesso em: $1^{\circ}$ jul. 2021. 
ções para os moradores da cidade. Burilando o argumento nos seus textos posteriores, Lima aponta as perdas decorrentes do modelo de urbanização adotado no Rio, mas em nuance mais complexa:

Esses nomes tupis, nos acidentes naturais das cercanias da cidade, são os documentos mais antigos que ela possui das vidas que aqui floresceram e morreram. [...]

Há, parece, na fatalidade destas terras, uma necessidade de não conservar impressões das sucessivas camadas de vida que elas deviam ter presenciado o desenvolvimento e o desaparecimento. [...] e todos sabem que, quando uma turma de trabalhadores, em escavações de qualquer natureza, encontra uma igaçaba, logo se apressam em parti-la, em destruí-la como cousa demoníaca ou indigna de ficar entre os de hoje. A pobre talha mortuária dos tamoios é sacrificada impiedosamente (BARRETO, 2010, p. 141-142).

De fato, os jornais do Rio noticiavam que das escavações profundas eram retirados achados arqueológicos: vários objetos, utensílios e magníficas igaçabas contendo ossos de indigenas ${ }^{9}$. Em vez de destinar esses achados ao Museu Nacional, eles eram encaminhados à prefeitura, à polícia, ao necrotério ou simplesmente destruídos. Diante disso, Lima vê o país pelo prisma da fatalidade: o Brasil não tem como dar certo.

Tal visão explica uma carta datada de 18 maio de 1920, na qual Lima criticava o patriotismo do amigo Lobato, então em pleno fervet opus da nova casa editora, "pretende criar de uma assentada muitas coisas nestes Brasis" (CAVALHEIRO, 2017, p. 81). Lima adverte-o de que num país onde não há vestígios do seu próprio passado, dificilmente vai se criar algo de seu. Ao "pessimismo fecundante" que Antonio Candido atribui à obra de Lobato, opõe-se o pessimismo fatalista da escrita de Lima.

Quanto a Inhaúma, observamos que o bairro tem certo parentesco com o subúrbio paulista do Brás, onde mora Pedrinho, protagonista de "O fisco". Embora haja diferenças consideráveis entre um bairro operário populoso de São Paulo e um bairro rural próximo ao centro do Rio, com seus ranchos cercados de árvores e galinhas nos quintais, embora possuam perfis humanos distintos, um habitado por brasileiros e imigrantes de vários países (a maioria da Itália), outro habitado por brasileiros em sua maioria negros e mestiços, Inhaúma e Brás espelham um ao outro na tragédia que os irmana: a pobreza.

Agrupando comunidades de baixa ou nenhuma renda, a Inhaúma de Lima era dos biscateiros, donos de venda, carroceiros, lavadeiras, carvoeiros, prostitutas, bêbados, curandeiros, médiuns e macumbeiros. Lima descreve bem o amálgama de religiosidades daquele povo - por exemplo, os terreiros dos arredores, que serviam como espaço de resistência para a prática das tradições religiosas de matriz africana, que eram proibidas e perseguidas pela polícia.

Lima também contrapõe os "médiuns que curam" aos médicos famosos e defende que o médium, o feiticeiro e o macumbeiro estão muito mais próximos do povo humilde do que os padres. "A Igreja católica unicamente não satisfaz o nosso povo humilde. É quase abstrata para ele, teórica” (BARRETO, 2010, p. 143).

9 Uma pesquisa na Hemeroteca Digital da Biblioteca Nacional do período de 1900 a 1919 confirma a informação incorporada no conto. Como exemplo, ver Pereira da Silva (1911). 
Já em "Negrinha", a igreja católica é satirizada em tal nivel, que chega à derrisão. Inácia representa a hipocrisia das beatas, pois proclama-se bondosa enquanto pratica o crime hediondo da tortura - com o terço numa mão e o chicote na outra. A caracterização dessa personagem abjeta é tão rica de nuances em sua monstruosidade, que o narrador não deixa alternativas ao leitor senão odiá-la.

O Brás de Lobato não tem igreja: tem os operários semiescravizados das fábricas, as crianças em trabalho infantil, pequenos comerciantes e o baixo clero do funcionalismo público (fiscais de rua da prefeitura ou da força policial), além de marceneiros, ferreiros, advogados, recepcionistas, alfaiates, técnicos, professores, comerciantes. Ali conviviam brasileiros descendentes de escravos e famílias de imigrantes, gente de todas as cores. Em vez do barracão, o cortiço, as casinhas de platibanda com aluguel exorbitante.

O Brás trabalha de dia e à noite gesta. Aos domingos fandanga ao som do bandolim. [...], nos dias feriados o Brás vem a São Paulo.

Entope os bondes no travessio da várzea e cá ensardinha-se nos autos: o pai, a mãe, a sogra, o genro e a filha casada no banco de trás; o tio, a cunhada, o sobrinho e o pepino escoteiro no da frente; filhos miúdos por entremeio; filhos mais taludos ao lado do motorista; filhos engatinhantes debaixo dos bancos; filhos em estado fatal no ventre bojudo das matronas. Vergado de molas, o carro geme sob a carga e arrasta-se a meia velocidade, exibindo a Paulicéia aos olhos arregalados daquele exuberante cacho humano.

[...]

O Brás devora tudo, ruidosa, alegremente e, com massagens ajeitadoras do abdome, sai impando bem-aventurança estomacal. Caroços de azeitonas, palitos de camarões, guardanapos de papel, pratos de papelão seguem nas munhecas da petizada como lembrança da festa e consolo ao bersalherzinho que lá ficou de castigo em casa, berrando com goela de Caruso.

Em seguida, toca para o cinema! O Brás abarrota os de sessão corrida. O Brás chora nos lances lacrimogêneos da Bertini, e ri nas comédias a gás hilariante da L-Ko mais do que autorizam os mil e cem de entrada. E repete a sessão, piscando o olho: é o jeito de dobrar a festa em extensão e obtê-la a meio preço550 réis, uma pechincha (LOBATO, 1946a, p. 65).

No Brás vive Pedrinho e a sua pobre familia. O pai, José, trabalha num moinho de trigo e ganha miseravelmente pelo seu trabalho. Tem depressão e lida com os problemas consumindo bebidas alcoólicas em excesso. Mariana, mãe de quatro filhos, dos quais Pedrinho é o mais velho, apesar de ter apenas 27 anos, aparenta o dobro da idade. O serviço doméstico incessante a consome, além das demandas da maternidade, entre os partos sucessivos e o aleitamento. Dez anos de casada não são um problema, o seu maior desespero é o fisco. São os impostos abusivos cobrados pelo governo que retiram a comida do prato da sua família.

\section{As CRIANÇAS PROtagonistas de Lima E de Lobato}

A recorrência de temas e personagens infantis em grande número de contos para adultos de Monteiro Lobato já fora observada por outros pesquisadores (BIGNOTTO, 2000; MARTINS, 2003). Em Lima Barreto, dá-se o oposto: as crianças são, em geral, uma ausência - por isso o conto "O moleque" chama a nossa atenção. 
Enquanto Lima viveu celibatário e sem filhos, Lobato era casado e tinha quatro crianças. Em dezembro de 1918, Marta, Edgard, Guilherme e Rute tinham, nove, oito, seis e dois anos de idade, respectivamente. A experiência pessoal pode ter exercido especial influência sobre a sensibilidade de Lobato diante da precariedade de direitos de que era vítima a criança brasileira nos anos próximos de 1920.

No conto "Negrinha", a atmosfera é funesta, o foco da narrativa é compacto e denso. Ao leitor, não é dito onde nem quando se passa, embora se possa inferir que a história ocorra imediatamente após a Abolição, ainda no século XIX. Nasceu na senzala, de mãe escrava, ficou órfã aos quatro anos e desde então sua única função era a de saco de pancadas de seu algoz, Dona Inácia. Tudo se passa no circunscrito espaço doméstico, em um núcleo mínimo de personagens, e o enredo se restringe às torturas cotidianas praticadas por Dona Inácia, interrompidas pelo único dia na vida em que Negrinha foi criança - o dia em que brincou.

A descrição das crianças protagonistas de cada conto indica que Zeca era o mais afortunado dos três, pois era o único que tinha boa aparência e asseio, recebendo da sua mãe os cuidados que a infância demanda. Pedrinho era o mais velho de quatro filhos, a mãe cuidando dos menores e o pai trabalhando na fábrica o dia todo; sentia-se no dever de trabalhar para ajudar a alimentar sua família e minimizar o sofrimento de seus pais.

Negrinha era sozinha no mundo. Magra, atrofiada, quase não falava, e quase não andava, que era para não estragar as plantas da casa. Como se fosse um vaso ou um animal adestrado de Dona Inácia, "A boa senhora punha-a na sala, ao pé de si, num desvão da porta” (LOBATO, 1946a, p. 22). E assim a sua humanidade lhe era negada em cada gesto pela sádica tutora. Vamos às descrições.

"Preta? Não; fusca, mulatinha escura, de cabelos ruços e olhos assustados. [...] seus primeiros anos vivera-os pelos cantos escuros da cozinha sobre velha esteira e trapos imundos" (LOBATO, 1946a, p. 21). Assim era e vivia Negrinha. Pedrinho, por sua vez, tem "Nove anos. Franzino, doentio, sempre mal alimentado e vestido com os restos das roupas do pai” (LOBATO, 1946b, p. 67). Já o moleque Zeca é um caso diferente:

[Zeca era] um pretinho de pele de veludo, macia de acariciar o olhar, com a carapinha sempre aparada pelos cuidados da mão de sua mãe, e também com as roupas sempre limpas, graças também aos cuidados dela.

Tinha todos os traços de sua raça, os bons e os maus [...] (BARRETO, 2010, p. 146-147).

O tom com que o narrador fala de Zeca, tanto nesse quanto em outros trechos do conto, é cheio de ternura e compaixão. O aposto no trecho - "os bons e os maus" - sugere que o narrador de Lima Barreto admitiria uma relação entre raça e traços hereditários (bons e maus), o que contradiz a postura crítica do autor frente às teorias raciais em curso naquele momento. Ambivalências como essas, inerentes à história do nosso país e à própria cultura brasileira, manifestam-se nas brechas da narrativa em outros textos do escritor, o que pode ser assunto para um outro trabalho.

"O fisco" foi publicado originalmente na Revista do Brasil, em 1918, mesmo ano de "O moleque" e da pandemia de gripe espanhola. Cumpre observar alguns 
fatos em torno desse período. Em 1917, médicos sanitaristas denunciavam na imprensa a precariedade das condições de trabalho para os menores de idade. No mesmo ano, a chamada grande greve dos operários em São Paulo reivindicava, entre outras pautas, o fim do trabalho infantil. Os jornais estampavam mortes, ferimentos e mutilações ocorridas em acidentes que eram rotina nas fábricas. Crianças eram vítimas do trabalho, mas também da fome, da doença e da violência.

Em 1919, é criada a Organização Internacional do Trabalho. No mesmo ano, o Departamento Estadual do Trabalho de São Paulo faz uma visita de fiscalização em 19 fábricas do setor têxtil. O resultado é estarrecedor: 40\% de todos os empregados neste setor da indústria são menores de idade ${ }^{10}$. Faz sentido pensar sobre o modo como essas realidades repercutem na literatura da época.

\section{CONSIDERAÇÕES FINAIS: O PÁTHOS COMO ELEMENTO UNIFICADOR}

Os narradores dos contos "O moleque", "O fisco" e "Negrinha" são oniscientes, isto é, falam em terceira pessoa e não participam diretamente dos fatos que contam. Nos contos em questão, observamos que os três narradores construídos por Lobato e por Lima Barreto emitem juízos de valor e tomam partido: eles sempre estão do lado dos sofredores da história. No caso de Lobato, há um duplo movimento patético mobilizando as emoções do leitor: piedade pela criança sofredora e indignação contra o adulto que provoca o seu martírio. Quanto ao Pedrinho, é o fiscal de tributos do município o seu opressor:

O caso girava em torno de uma criança maltrapilha, que tinha a tiracolo uma caixa tosca de engraxate, visivelmente feita pelas suas próprias mãos. Muito sarapantado, com lágrimas a brilharem nos olhos cheios de pavor, o pequeno murmurava coisas de ninguém atendidas. Sustinha-o pela gola um fiscal da Câmara.

- Então, seu cachorrinho, sem licença, hein? - exclamava entre colérico e vitorioso o mastim municipal, focinho muito nosso conhecido. É um que não é um mas sim legião, e sabe ser tigre ou cordeiro conforme o naipe do contraventor.

A miserável criança evidentemente não entendia, não sabia que coisa era aquela de licença, tão importante, reclamada assim a empuxões brutais. Foi quando entrou em cena o policia (LOBATO, 1946b, p. 54).

Em "Negrinha", há um equilíbrio na construção minuciosa das duas protagonistas que atuam em polos antagônicos da narrativa: a criança oprimida e adulta opressora. A ironia e o sarcasmo impiedosos com que Lobato vai pintando o retrato de Inácia fazem com que se associem à sua figura os sentimentos mais poderosos de aversão e raiva. Já é clássica a insuportável cena de tortura do ovo quente na boca da menina. Por meio da vulgaridade e da obscenidade de Dona Inácia, Lobato levou o sofrimento de Negrinha ao paroxismo. Pedimos licença para exemplificar com uma citação muito longa e conhecida.

Excelente senhora, a patroa. Gorda, rica, dona do mundo, amimada pelos padres, com lugar certo na igreja e camarote de luxo no céu. Entaladas as banhas

10 Para maiores detalhes, cf. Moura (1991). 
no trono uma cadeira de balanço na sala de jantar, - ali bordava, recebendo as amigas e o vigário, dando audiências, discutindo o tempo. Uma virtuosa senhora, em suma - "dama de grandes virtudes apostólicas, esteio da religião e da moral", dizia o padre.

Ótima, a D. Inácia.

Mas não admitia choro de criança. Ai! Punha-lhe os nervos em carne viva. Viúva sem filhos, não a calejara o choro da sua carne, e por isso não suportava o choro da carne escrava. Assim, mal vagia, longe na cozinha, a triste criança, gritava logo, nervosa: - Quem é a peste que está chorando aí?

[...]

A excelente D. Inácia era mestra na arte de judiar de crianças. Vinha da escravidão, fora senhora de escravos e daquelas ferozes, amigas de ouvir contar o bolo e estalar o bacalhau. Nunca se afizera ao regímen novo - essa indecência de negro igual a branco [...].

O 13 de maio tirou-lhe das mãos o azorrague, mas não the tirou da alma a gana. Conservava, pois, Negrinha em casa como remédio para os frenesis. Simples derivativo.

- Ai! Como alivia a gente uma boa roda de cocres bem fincados!...

Tinha de contentar-se com isso, judiaria miúda, os níqueis da crueldade: cocres, mão fechada com raiva e nós de dedos que cantam no coco do paciente. Puxões de orelha: o torcido, de despegar a concha (bom! bom! bom! gostoso de dar!) e o a duas mãos, o sacudido. A gama dos beliscões: do miudinho, com a ponta da unha, a torcida do umbigo, equivalente ao puxão de orelha. A esfregadela: roda de tapas, cascudos, pontapés e safanões à uma-divertidissimo! A vara de marmelo, flexivel, cortante: para "doer fino", nada melhor! (LOBATO, 1946a, p. 21-23).

Pela clareza dessa denúncia, Negrinha, de par com outros contos e crônicas do escritor, entra em rota de colisão com interpretações univocas da literatura de Lobato. Tais leituras de sua obra não reconhecem as contradições nela presentes e as mudanças pelas quais passou o pensamento do escritor ao longo da sua vida, haja vista o amadurecimento que transformou positivamente a sua compreensão quanto ao problema social e econômico do Brasil nos 32 anos que separam o Jeca-Tatu (1914) do Zé Brasil (1946). Outros textos podem ser reveladores da ambivalência e da evolução do pensamento de Lobato quanto à questão racial ${ }^{11}$.

Por fim, consideramos que a desventura de Zeca, relatada no conto "O moleque", foi mais sutil do que se viu nas outras duas personagens mencionadas. Chamado sempre de "gibi", "moleque", e "negro" pelos meninos da vizinhança, Zeca resolvera se vingar. O epíteto indicativo de sua cor preta era, para Zeca, um desrespeito insuportável, pela ridicularização a que ele se sentia exposto. O bullying abala a autoestima de Zeca e ele aceita a oferta do coronel Castro, vizinho que lhe tinha muita estima e consideração: ganha uma fantasia de diabo para assustar e dar o troco nos meninos assediadores.

O temor da mãe de Zeca, supondo que a fantasia tivesse sido roubada pelo seu filho, é indicativo do antigo estigma de que ainda sofrem os brasileiros nas-

11 "O jardineiro Timóteo", "O drama do Brio", "Quero ajudar o Brasil" e "O 22 da Marajó" são alguns exemplos. 
cidos pretos em nossa sociedade. Hoje, ostensivamente vigiados pelas câmeras e pelos olhares acusadores das pessoas, jovens negros são agredidos e atormentados por falsas acusações de roubo em lojas e supermercados, de modo que as mães de meninos negros de periferias como Inhaúma, por fracasso de nossas politicas públicas educacionais em superar o racismo que estrutura a nossa cultura, continuam a sentir os receios de Dona Felismina.

Como se falasse também de Lima, Resende (2014) analisa o polo central em torno do qual orbitam as personagens da ficção de Lobato: os pobres, em toda a gama de possibilidades de sua expressão. Assim como Lima, Lobato mostra-se atento a todos eles: do preto descendente de escravizados ("Negrinha", "O jardineiro Timóteo", "Os negros") que virou agregado de fazenda ao estudante vendendo seus livros por uma ninharia para comprar comida ("Duas cavalgaduras"); do imigrante miserável explorado em fábricas ("O fisco") à empregada doméstica ("Dona Expedita") tratada debaixo dos pés da patroa; das crianças que brincam com bois de chuchu às crianças que não brincam - aquelas cuja realidade não lhes permite sonhar. A prefaciadora dos contos completos de Lobato bem observa que o estafeta de "Um suplício moderno", funcionário público dos Correios, "é antes uma vítima do que um beneficiado pelo Estado" (RESENDE, 2014, p. 19), trabalhando em condições extremamente precárias por remuneração aviltante.

As tintas com as quais Lima Barreto e Monteiro Lobato pintam a realidade dramática do povo brasileiro, imposta pelo atraso social fabricado por um sistema econômico que o escritor paulista ainda não compreendia em toda a sua complexidade, possuem tons vibrantes e produzem matizes diversos de sentido. As estratégias discursivas e narrativas de que se valem parecem convergir na medida em que são capazes de suscitar no leitor sentimentos de empatia, piedade, tristeza, revolta e ternura. A veemência com que apresentam a tragédia de suas personagens parece servir a um propósito de reconfiguração social, a um apelo por mudanças naquele Brasil de 100 anos atrás. Gritos por humanidade e igualdade ecoam das páginas dos três contos analisados neste trabalho.

\title{
Three SHORT STORIES By LIMA BARRETo AND MONTEIRo Lobato: INVEsTigating BRAZIL-REPUBLIC
}

\begin{abstract}
Lima Barreto's tales confronted with the tales of Monteiro Lobato present several points of similarity in the perspective adopted by each one when thinking about Brazil. However, thinking about Brazil as a mere philosophical or discursive exercise was not the style of these writers: the pen is at the service of greater causes, collective pain and national struggles. In this study we compare the short stories "O moleque" (BARRETO, 2010 [1918]), "O fisco" (LOBATO, 1946b) and "Negrinha" (LOBATO, 1946a).
\end{abstract}

Keywords: Lima Barreto. Monteiro Lobato. "O moleque". "O fisco". "Negrinha". 


\section{REFERÊNCIAS}

BARBOSA, F. de A. A vida de Lima Barreto (1881-1922). 2. ed. rev. Rio de Janeiro: José Olympio, 1959. (Coleção Documentos Brasileiros).

BARRETO, L. Impressões de leitura e outros textos críticos. 1. ed. São Paulo: Penguin Classics Companhia das Letras, 2017.

BARRETO, L. O moleque. In: SCHWARCZ, L. M. (org.). Contos completos de Lima Barreto. São Paulo: Companhia das Letras, 2010. p. 141-151.

BARRETO, L. Recordações do escrivão Isaías Caminha. 10. ed. São Paulo: Ática, 2007 [1909]. (Série Bom Livro).

BIGNOTTO, C. C. Personagens infantis da obra para crianças e da obra para adultos de Monteiro Lobato: convergências e divergências. 2000. 166 f. Dissertação (Mestrado em Letras) - Instituto de Estudos da Linguagem, Universidade Estadual de Campinas, Campinas, 2000.

BOSI, A. História concisa da literatura brasileira. São Paulo: Cultrix, 1994.

CAMARGOS, M. Villa Kyrial: crônica da belle époque paulistana. São Paulo: Senac, 2000.

CANDIDO, A. Monteiro Lobato. Folha da Manhã, 10 dez. 1944.

CAVALHEIRO, E. A correspondência entre Monteiro Lobato e Lima Barreto: com notas, manuscritos e acréscimos. Organização de Valéria Lamego. 2. ed. Rio de Janeiro: Verso Brasil, 2017.

HOUAISS. UOL, [s. d.]. Disponivel em: https://houaiss.uol.com.br/corporativo/ apps/uol_www/v5-4/html/index.php\#12. Acesso em: 30 jun. 2021.

LOBATO, M. O imposto único: conto do Natal. Revista do Brasil, São Paulo, v. XI, ano 3, n. 36, p. 419-429, dez. 1918.

LOBATO, M. Negrinha. In: LOBATO, M. Negrinha. São Paulo: Brasiliense, 1946a. (Obras Completas).

LOBATO, M. O fisco. In: LOBATO, M. Negrinha. São Paulo: Brasiliense, 1946b. (Obras Completas).

LOBATO, M. A barca de Gleyre. São Paulo: Brasiliense, 1964. (Obras Completas). t. 2 .

MARTINS, M. R. Lobato edita Lobato: história das edições dos contos lobatianos. 2003. 418 f. Tese (Doutorado em Letras) - Instituto de Estudos da Linguagem, Universidade Estadual de Campinas, Campinas, 2003.

MOREIRA, P. Os clowns de Machado de Assis, Lima Barreto e Monteiro Lobato. Machado de Assis em Linha, v. 7, n. 14, p. 99-119, 2014. Disponivel em: https:/ / www.scielo.br/j/mael/a/T4kyvZvnc5JkcTzwSssBJ3c/?lang=pt. Acesso em: 24 jun. 2021.

MOURA, E. B. B. Infância operária e acidente de trabalho. In: DEL PRIORE, M. História da criança no Brasil. São Paulo: Contexto, 1991. p. 112-128.

PEREIRA, L. M. Prenúncios modernistas - Lima Barreto. In: História da Literatura Brasileira: prosa de ficção - de 1870 a 1920. Rio de Janeiro: José Olympio, 1950. p. 272-302.

PEREIRA DA SILVA, A. G. A aldeia de Araryboia em S. Christovão. O Paiz, 21 jan. 1911. p. 2. 
PRADO, A. A. A correspondência entre Lima Barreto e Monteiro Lobato. In: PRADO, A. A. Trincheira, palco e letras: crítica, literatura e utopia no Brasil. São Paulo: Cosac Naify, 2004. p. 207-215.

RESENDE, B. Os imprescindiveis contos de Monteiro Lobato. In: LOBATO, M. Contos completos. São Paulo: Biblioteca Azul, 2014.

SCHWARCZ, L. M. Ó Lima! Ó Lobato! Cartas mostram as afinidades eletivas entre o homenageado da Flip e o editor paulista. Quatro Cinco Um, $1^{\circ}$ jul. 2017. Disponivel em: https://www.quatrocincoum.com.br/br/resenhas/1/o-lima-olobato. Acesso em: 2 jul. 2021.

SCHWARCZ, L. M.; STARLING, H. M. Brasil: uma biografia. 2. ed. São Paulo: Companhia das Letras, 2018.

SEVCENKO, N. Literatura como missão. 2. ed. São Paulo: Companhia das Letras, 2003.

SILVA, M. V. C.; BERGAMO, E. A língua na nação pré-modernista em contos de Lima Barreto e Monteiro Lobato. Comunicaciones en Humanidades, n. 2, p. 22-33, 2012. Disponivel em: http://revistas.umce.cl/index.php/Comunicaciones/issue/view/87. Acesso em: 24 jun. 2021.

TIN, E. Que obra preciosa estás a fazer!: considerações sobre as cartas do editor Monteiro Lobato ao escritor Lima Barreto. Opiniães, n. 11, p. 19-35, 2017. DOI 10.11606/issn.2525-8133.opiniaes.2017.142088. Disponivel em: https://doi. org/10.11606/issn.2525-8133.opiniaes.2017.142088. Acesso em: 20 jun. 2021. 